\title{
Kilka uwag na marginesie sporu między Gregorym S. Kavka a Williamem Neblettem o poczucie winy
}

DOI: http://dx.doi.org/10.12775/RF.2016.013

\section{Wprowadzenie}

Celem artykułu jest przedstawianie dyskusji na temat poczucia winy, której ślady znaleźć można w zbiorku Filozofia moralności. Kara, wina, wybaczenie, z serii prezentującej fragmenty filozofii analitycznej ${ }^{1}$. W polemice spierały się ze sobą dwa poglądy. Z jednej strony, mówiący o konieczności częściowego ograniczenia roli poczucia winy w życiu moralnym. Z drugiej strony, broniący klasycznego rozumienia roli poczucia winy. Zwolennikiem zmiany tradycyjnego ujęcia poczucia winy i jego roli był William Neblett, który odnosił się też do propozycji radykalnego odrzucenia poczucia winy. Poglądy te prezentuje artykuł, zamieszczony w przywołanej antologii². Jego adwersarzem, był Gregory S. Kavka.

1 Filozofia moralności. Wina, kara, przebaczenie, red. J. Hołówka, przeł. D. Gałecki, A. Lipszyc, P. Łuków, M. Rychter, Ł. Sommer, S. Stecko, Fundacja Aletheia, Warszawa 2000. Omówienie zagadnienia winy znajdzie czytelnik również w artykułach zawartych w: Filozofia chrześcijańska, red. K. Stachewicz, t. 9, 2012, s. 7-89. Znajdują się tu artykuły: R. Wiśniewski, Wina jako węzeł moralności; K. Wieczorek, Skąd przychodzi wina? Aksjologiczne i dialogiczne źródła zawinienia; A. Wierzbicki, Wina i sumienie. Komentarz etyczny do epilogu "Zbrodni i Kary" Fiodora Dostojewskiego; J. Giebułtowski, R. Piłat, Przyznanie się. Teoretyczne trudności zwiąane z przypisywaniem sobie działań; P. Strzyżyński, Problem trafu moralnego i winy według Thomasa Nagela i Norvina Richardsa.

2 W. Neblett, Etyka winy, w: Filozofia moralności. Wina, kara, przebaczenie, s. 66-80. 
Obie wypowiedzi pojawiły się pierwotnie podczas sympozjum Amerykańskiego Stowarzyszenie Filozoficznego w grudniu 1978 roku $^{3}$. Mimo że od tamtej pory minęło już sporo czasu, problem wydaje się być nadal aktualny, gdyż stawia pytania o rolę poczucia winy w życiu moralnym jednostek i społeczeństw.

Oprócz prezentacji argumentów obu stron, artykuł zawiera też próbę wyjaśnienia drobnego nieporozumienia jakie, jak sądzę, zaistniało między Neblettem a Kavką. Ponadto artykuł przedstawi dodatkowe racje przeciw argumentacji całkowicie odrzucającej poczucie winy.

\section{Argumentacja Nebletta}

W swoim artykule, Neblett opisuje fakty dotyczące poczucia winy. Stwierdza między innymi, że poczucie to posiada różną długość i intensywność, potrafi motywować do działania zarówno prawego, jak i złego, pojawia się rzadziej lub częściej u różnych ludzi, może być skorelowane z czymś, co zrobiliśmy, jak i z czymś, czego nie zrobiliśmy ${ }^{4}$.

Społeczeństwo wydaje się promować posiadanie poczucia winy. Brak takowego poczucia spotyka się z potępieniem, a przestępca, który wyraża poczucie winy jest łagodniej oceniany, niż przestępca bez takowych odczuć. Neblett zauważa też, że moralność zwyczajowa: gani za niewłaściwy sposób odczuwania winy, wymaga szczerości w poczuciu winy, krytykuje na przykład wmawianie sobie poczucia winy, chociaż nadmiar poczucia winy jest oceniany jako oznaka wrażliwości moralnej, uważa, że wina powinna być proporcjonalna do wykroczenia. Uważa się też: że poczucie winy jest powiązane z szacunkiem i współczuciem wobec innych, że odsłania nasze człowieczeństwo, powinno ono być autonomiczne, to znaczy niezależne od tego, czy inni przypisują nam winę czy też nas chwalą. Społeczeństwo potrafi też manipulować poczuciem winy tak, aby umiejętnie je wywołując, móc generować odpowiadające jemu (społeczeństwu) postawy ${ }^{5}$.

Wobec tego tradycyjnego i zazwyczaj akceptowanego ujęcia "poczucia winy" pojawiła się radykalna krytyka, wskazująca na jego zbędność, a nawet szkodliwość. Neblett prezentuje schematyczne ujęcie takiego stanowiska po to, by dzięki jego krytyce powrócić do tradycyjnego poglądu na temat winy, wzbogaconego o pewne elementy stanowiska radykalnego.

Schemat radykalny, zawiera następujące tezy: „(i) Poczucie winy, a zwłaszcza nadmierne poczucie winy może być dla jednostki szkodli-

3 Por. ibidem, przyp. 1, s. 66.

4 Ibidem, s. 67.

5 Ibidem, s. 68. 
we, a także może szkodzić innym... (ii) Manipulowanie cudzym poczuciem winy dla osiągnięcia dobrych celów rzadko wynika z dobrych zamiarów i często jest wyłącznie środkiem, za pośrednictwem którego krzywdzi się i zawstydza ludzi, realizując przy tym inne, ukryte cele... (iii) podejmowanie słusznych działań wyłącznie po to by «stłumić nieprzyjemne uczucia» (chodzi o poczucie winy, które tłumi się zaprzestając złego działania lub wynagradzając wyrządzone szkody - dop. P.S.), nie jest postępowaniem, które zasługiwałoby na poparcie lub moralną pochwałę. (iv) słuszne działanie powinno wypływać z «uczuć pozytywnych», takich jak troska, współczucie, lojalność, a nie z uczuć «negatywnych» takich jak poczucie winy"6. Powyższe tezy prowadza, zdaniem Nebletta, do rozbudowanej konkluzji, którą cytuję w całości: „Człowiek dobry moralnie jest zatem człowiekiem, którego działanie wypływa z pozytywnych uczuć, którego słuszne czyny nie mają źródła w czysto egoistycznym pragnieniu stłumienia przykrych uczuć, a zwłaszcza przykrego poczucia winy. Człowiek dobry moralnie nigdy też nie zachęca innych do niby moralnego działania, które miałoby «tłumić przykre poczucie winy». Co więcej, skoro poczucie winy jest samo w sobie nieprzyjemne i skoro może utrudniać dążenie do osobistego szczęścia, stanowi prima facie uczucie, którego nie powinniśmy doznawać. Tak więc, człowiek dobry moralnie stara się nigdy nie działać z poczucia winy, nigdy nie manipulować poczuciem winy u innych i nigdy nie mieć jakiegokolwiek i w jakimkolwiek stopniu poczucia winy"7.

To radykalne stanowisko Neblett poddaje krytyce. Stwierdza między innymi, że tak pojmowane poczucie winy jest oderwane od wyrządzonego zła i przypomina przykre doznanie zmysłowe, którego trzeba się koniecznie pozbyć. Tymczasem, poczucie to często wiąże się z przekonaniem o konieczności naprawienia wyrządzonego zła, a czasem nawet gniewem na samego siebie z powodu owego zła. Radykał, zdaniem Nebletta, błędnie proponuje wyzbycia się poczucia winy, bez uporania

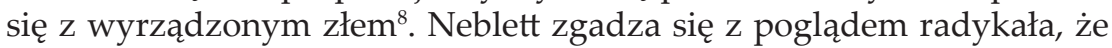
poczucie winy jest czymś złym, gdyż jest „przykre i bolesne” i czasami może mieć szkodliwy wpływ na ludzi, ale jednocześnie proponuje skierować ostrze ataku radykała nie tyle ku poczuciu winy jako takie$\mathrm{mu}$, co jego niewspółmiernym, do wyrządzonego zła, sposobom odczuwania9. Takie przesadzone reakcje mogą sprawiać niepotrzebny ból osobie odczuwającej winę. Neblett zauważa też, że poczucie winy nie musi z konieczności być tylko afektywne, ale że wiąże się z postawami poznawczymi, na przykład z "myśleniem, że”, ,przekonaniem, że”

\footnotetext{
6 Ibidem, s. 76.

7 Ibidem.

8 Ibidem, s. 76-77.

9 Ibidem, s. 77.
} 
uczyniło się coś złego ${ }^{10}$. Najważniejszy jednak argument przeciw radykalnemu odrzuceniu poczucia winy dotyczy konsekwencji stanowiska radykalnego. Jest nią uznanie twierdzenia, że nawet człowiek moralnie zły nie powinien mieć poczucia winy. Co, zdaniem Nebletta, jest bardzo kontrowersyjne i nie do przyjęcia ${ }^{11}$. Wobec tak mocnej krytyki powstaje pytanie o znaczenie propozycji radykała. Trudno bowiem przyjąć, że radykałowi chodziło o coś tak banalnego jak stwierdzenie, że "osoba dobra moralnie nie miałaby okazji do odczucia winy"; jeśli natomiast „obstaje on przy ideale człowieka wolnego od poczucia winy, jego sąd w odniesieniu do ludzi złych moralnie wydaje się nie do przyjęcia"12. Neblett proponuje więc ograniczyć propozycję radykalną do ,jednostek, których postępowanie i uczucia niezmiennie zasługują na wysokie lub stosunkowo wysokie moralne uznanie"13. Osoby te mogłyby „,zaniechać poczucia winy z powodu zwyczajnych, codziennych moralnych potknięć" ${ }^{14}$. Taka postawa pozwoliłaby "pominąć pozytywną rolę, jaką poczucie winy może czasem odgrywać w działaniu moralnym i moralnej poprawie, z racji górujących nad tą zaletą wad"15. Chodzi o wady wspomniane powyżej. Stanowisko złagodzone staje się bardziej wiarygodne niż radykalne, przy założeniu, że jest się właśnie całkowicie lub prawie idealną osobą. Neblett zauważa też, że nie jest zwolennikiem odrzucenia tradycyjnego poglądu na rolę winy w życiu moralnym, ale że radykalne stanowisko jest „płodną krytyką", która podkreśla wagę własnego rozwoju moralnego, potrzebę wybaczania sobie samemu i paradoksalnie prawo i zdolność do naprawy naszych win ${ }^{16}$.

\section{Kryłyka Karki}

Przeciw argumentacji Nebleta wystąpił G.S. Kavka na wspomnianym wyżej sympozjum. Streszczeniem tamtego referatu jest wypowiedź zatytułowana "Zły czyn i wina”, do której bezpośrednio odnosi się poniższy artykuł ${ }^{17}$. Zdaniem Kavki, Neblett popełnia błąd w ocenie natury poczucia winy. Zakłada bowiem, całkowicie niesłusznie, że człowiek ma poczucie winy tylko wobec czegoś, czego faktycznie dokonał. Kavka stwierdza, że założenie to jest nie do pogodzenia z jakimkolwiek czysto fenomenologicznym wyjaśnieniem poczucia winy, które przed-

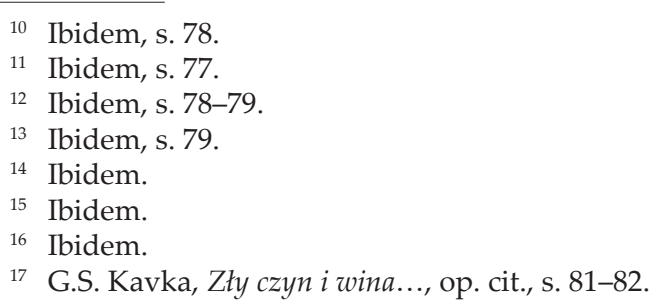


stawia je po prostu jako wydarzenie mentalne o pewnym zabarwieniu uczuciowym $^{18}$. Jak można się domyśleć, bez koniecznego połączenia z uprzednim złym czynem. Kavka zauważa też, że założenie Nebleta „uświadamia, że możliwość doznania poczucia winy z powodu jakiegoś zajścia, ogranicza nie tylko obiektywna natura tego zajścia, ale i to, co myśli o nim sam podmiot moralny"19. Tymczasem na przykład w sytuacjach, w których podmiot musi wybrać mniejsze zło, może pojawić się poczucie winy bez de facto czynu intencjonalnie złego. Kavka stwierdza, że „w tego typu sytuacjach, nawet jeśli podmiot wybierze lepsze, a tym samym moralnie słuszne wyjście, może spowodować cierpienie innych i pogwałcić zasadę moralną którą uznaje. W takich okolicznościach podmiot może trwać $\mathrm{w}$ przeświadczeniu, że nie postąpił źle, a mimo to mieć poczucie winy z powodu zadanego cierpienia lub pogwałcenia własnych zasad"20.

Zdaniem Kavki zdarza się też, że ludzie czują się winni nawet $\mathrm{w}$ takich sytuacjach, w których kompletnie nic nie uczynili, które z nimi samymi jako autorami działań nie mają nic wspólnego ${ }^{21}$.

Wydaje się więc, że Nebletta doskonały moralnie podmiot mógłby mieć poczucie winy bez de facto winy moralnej. Na przykład wówczas, gdy musiałby wybrać między zadaniem cierpienia lub złamaniem własnych zasad moralnych, lub też gdyby urodziło się w nim poczucie winy wobec na przykład czyjegoś nieszczęścia i własnej bezsilności.

Co więcej, zdaniem Kavki, takie nieuzasadnione poczucie winy jest korzystne zarówno z punktu widzenia perfekcjonizmu, jak i pragmaty$z m u$, rozumianych tutaj jako systemy etyczne ${ }^{22}$.

Powyższe argumenty prowadzą do takich $\mathrm{m}$. in. konkluzji. Po pierwsze, nie istnieje w sposób ogólny i konieczny podmiot moralnie doskonały lub prawie doskonały, który nie mógłby odczuwać winy bez powodu. Po drugie, wobec powyższego konstrukcja Nebletta, czyli „radykalizm osłabiony" pozbawiona zostaje podstawowego założenia, że podmiot doskonały lub prawie doskonały z konieczności nie ma poczucia winy. Po trzecie, Kavka albo opowiada się za radykalizmem przeciw tradycyjnemu ujęciu, albo odwrotnie. Skoro jednak uważa, że poczucie winy bez czynu bywa pożądane, to przeciwstawia się osłabionej wersji radykalizmu. Zatem, z konieczności odrzuca stanowisko radykalne $\mathrm{w}$ jakiejkolwiek postaci. Skoro bowiem odrzuca słabszą wersję przy jednoczesnym podkreślaniu roli wyrzutów sumienia, to tym bardziej będzie przeciw nie osłabionej wersji radykalnej.

\footnotetext{
18 Ibidem, s. 81.

19 Ibidem.

20 Ibidem.

21 Ibidem, s. 82.

22 Ibidem.
} 


\section{Kilka uwag na temat sporu}

Po pobieżnej lekturze obu artykułów odnieść można wrażenie, idąc za stwierdzeniami Kavki, że Neblett całkowicie odrzuca możliwość posiadania poczucia winy niezwiązanego z czynem. Przy bardziej wnikliwej lekturze okazuje się jednak, że powyższa interpretacja jest uproszczona. W artykule Nebletta znajdują się bowiem passusy mówiące wprost o możliwości istnienia poczucia winy bez złego czynu. Neblett wyraźnie to stwierdza. Kavka z pewnością też to zauważył. Jak więc wytłumaczyć, że krytykuje Nebletta jakoby za niedostrzeganie takowej możliwości? Sądzę, że nieporozumienie wynika z nieco innych założeń obu filozofów. Obaj przyjmują możliwość zaistnienia poczucia winy bez czynu, ale różnią się w rozumieniu owej możliwości. Tam gdzie Neblett mówi o doskonałym moralnie podmiocie, że nie ma poczucia winy, wyrazić chce raczej myśl, że podmiot taki nie powinien mieć wyrzutów sumienia. Dlatego że jeśli są one przesadzone, stają się szkodliwe. Czyli Neblett nie tyle mówi o niemożliwości faktycznej, co chce raczej wyrazić brak powinności posiadania poczucia winy. Z kolei Kavka, mówi o możliwości faktycznej i konieczności posiadania takiego poczucia winy. Zatem Kavka pojmuje uwagi Nebletta ze swojej perspektywy, jako ten drugi negował nie tyle fakt, co konieczność posiadania poczucia winy wobec niewyrządzonego zła. Źródłem sporu między autorami omówionych wypowiedzi, jak sądzę, jest zatem uprzedni stosunek do poczucia winy. Jak można było zauważyć, Neblett skłonny jest z radykałami podkreślać negatywne aspekty samego poczucia winy i budowania na nim moralności. Kavka przyjmuje raczej pogląd, że poczucie winy może, przynajmniej z punktu widzenia pragmatyzmu i perfekcjonizmu, być pożądane i pomagać $\mathrm{w}$ rozwoju moralnym, nawet jeśli nie jest adekwatne względem czynu. W dodatku spór ten dotyczy, tak naprawdę, tylko pewnej zawężonej grupy osób, nazwanych przez Nebletta moralnie doskonałymi lub prawie moralnie doskonałymi. Nie dotyczy natomiast osób złych czy moralnie niedoskonałych, tutaj obaj autorzy wydają się widzieć konieczną rolę wyrzutów sumienia. Nie tylko więc stwierdzają fakt takowych, ale i ich deontyczną konieczność. Neblett, jak cytowałem, nie zgadza się ze stanowiskiem radykalnym między innymi dlatego, że jego konsekwencją byłoby zaakceptowanie normy, że osoby moralnie złe nie powinny mieć wyrzutów sumienia. Kavka, odrzucając stanowisko radykalne, wydaje się implicite również nie zgadzać na wspomniane właśnie stanowisko.

Z owych presupozycji wynika próba obrony istnienia podmiotu idealnie moralnego, lub prawie idealnie moralnego, co zachodzi w wypadku Nebletta; i odpowiednio próba obalenia takiej możliwości w wypadku Kavki, co podważa fundament połączenia wersji radykalnej z tradycyjną. 
Czytając artykuł Nebletta odnieść można wrażenie, że autor po połączeniu wersji radykalnej z tradycyjną, nie potrafi się zdecydować, jaki status ma mieć owa tradycyjno-radykalna hybryda. Miast proponować jednoznaczne odrzucenie tradycyjnego poglądu, proponuje on zauważenie negatywnej roli poczucia winy, wyrugowanie owego poczucia u osób idealnie moralnych i docenienie stanowiska radykalnego, jako podkreślającego odpowiedzialność za dojrzałość moralną. Kavka skutecznie wykazuje, że druga propozycja jest nie do przyjęcia. Zatem z propozycji Nebletta, pozostaje tylko zauważenie negatywnej roli poczucia winy i zwrócenie uwagi na odpowiedzialność za własny rozwój moralny. Przyznać trzeba, że z tej perspektywy propozycja Nebletta jest mało odkrywcza. Jednocześnie jednak silnie prowokuje do postawiania radykalnych pytań o naturę poczucia winy i jego rolę.

Jednym z nich jest pytanie o to, czy tylko poczucie winy może przeszkadzać rozwojowi moralnemu. Przypomnę, że w radykalnej wersji owo przeszkadzanie zachodzi wówczas, gdy na przykład społeczeństwo wymusza reakcje poczucia winy za czyn. W domyśle chodzi tutaj o zachwianie albo i zburzenie autonomii moralnej, a przez to zaburzenie dojrzałości moralnej, której jak sądzę, autonomia jest elementem wymaganym.

Przymus społeczny, w postaci choćby wyrzutów z powodu braku poczucia winy, mógłby spowodować, że ktoś zostałby niejako zmuszony do przeżywania poczucia winy wobec uczynionego zła i miałby je przeżywać nieszczerze. Tak przynajmniej można rozumieć argumentację radykalnej wizji w ujęciu Nebletta. Co do tego stwierdzenia można jednak przedstawić pewne zastrzeżenia, których w omawianym artykule nie czyni Kavka, gdyż krytykuje samą możliwość konstruowania złagodzonej wersji, owego radykalnego odrzucenia poczucia winy. Po pierwsze, wydaje się, że zarzut wymuszania przez społeczeństwo, dotyczyć może nie tylko poczucia winy, ale głębiej idąc, samego pojmowania tego, co dobre, a co złe. Czyż to społeczeństwo nie próbuje wychować swoich członków do bycia dobrymi i posłusznymi? Broniąc autonomii, należałoby i tego zabronić społeczeństwu. Nie powinno ono narzucać i gwałcić autonomii oceny tego, co dobre, a tego, co złe, dokonywanej przez daną osobę. Najlepiej, gdyby w ogóle wyrugowano jakiekolwiek komunikaty, sugestie, wpływ wychowawczy dotyczące dobra lub zła, które sugerowałyby jak należy myśleć, czuć i co czynić. W ten sposób jednak, nie tylko niemożliwe byłoby budowanie norm moralnych i obyczajowych w społeczeństwie, ale zostałoby uniemożliwione jego funkcjonowanie. Bowiem bez owych komunikatów, sugestii i wychowawczych wpływów, społeczeństwo nie miałoby wspólnych odniesień etycznych i obyczajowych, gdyż odpowiednie normy i oceny w ogóle nie istniałyby $\mathrm{w}$ takim społeczeństwie, ponieważ zostałyby radykalnie wyrzucone jako mogące nieść ze sobą zagrożenie autonomii jednostki. Takie roz- 
wiązanie wydaje się więc być absurdalne i nieakceptowalne. Sam fakt wpływu społeczeństwa na postawy i oceny etyczne jednostek wydaje się niezbędny dla funkcjonowania tychże społeczeństw. Chyba że założyć, że każdy człowiek w sposób wrodzony posiada normy i oceny etyczne, i w dodatku ich przestrzega. Ostatnie sformułowanie jest jednak nie do utrzymania, gdyż nie tylko znane są przypadki osób, którym nie udało się owych norm przestrzegać, ale co więcej nieznane są przypadki osób, które owych norm przestrzegały zawsze i wszędzie. Tutaj więc wpływ społeczeństwa okazuje się niezbędny do tego, aby o przestrzeganiu norm przypominać i je egzekwować. Samo jednak przypominanie i egzekwowanie nie musi naruszać autonomii. Gdyby tak było, to każdy wpływ wychowawczy odnosiłby pełen sukces, a w sposób moralnie naganny postępowaliby tylko ci, którzy nie usłyszeli jeszcze jak należy postępować. Taki pogląd byłby zbliżony do sokratejskiego intelektualizmu etycznego, przynajmniej w prostej interpretacji poglądów Sokratesa i równie łatwo zostałby obalony, przez obserwację codziennych spraw i sprawek ludzkich ${ }^{23}$. Nie chcąc przypisywać zwolennikom poglądu radykalnego zbytniej naiwności, proponuję przyjąć, że nie tyle chcą oni wyrugować z życia moralnego poczucie winy, jako takie, co raczej nadużycia z nim związane. W czym zbliżam się do interpretacji Nebletta, z pewnym dodatkiem jednak. Łatwo z jednej strony przedstawić nadużycia, jakich może dopuścić się społeczeństwo wobec pojedynczej osoby, zwłaszcza wrażliwej, będące jeszcze dzieckiem czy nastolatkiem. Można tu wymienić choćby: sugerowanie nieadekwatnego poczucia winy, wówczas, gdy do takowego poczucia nie ma podstaw; wywoływanie i przywoływanie takowego poczucia w celu zdominowania danej osoby; czy także budowanie wzajemnych relacji wokół przede wszystkim tego, że dana osoba ma czuć się winna wobec kogoś innego. Takie nadużycia faktycznie wywołują nie tylko sprzeciw, ale i moralne oburzenie. Z drugiej strony nie można nie dostrzegać, że poczucie winy nie jest efektem tylko wpływów społeczeństwa. Jest ono też pochodną osobowości, a zwłaszcza wrażliwości danej osoby, która jest jego podmiotem. Tak jak mamy wpływ na nasz sposób odczuwania świata w ogóle, tak samo mamy wpływ na "definiowanie”, a także „przedefiniowanie" adekwatności i siły poczucia winy, jakie żywimy. Zwolennicy radykalnego potępienia poczucia winy, chcąc chronić przed jego wynaturzeniami, zdają się zakładać, że jako podmioty moralne nie mamy żadnego wpływu na nasze postawy i odczucia związane z winą; albo też zauważając taką możliwość, chcą na wszelki wypadek wyrugować w ogóle poczucie winy, w celu ochrony każdego przed pojawić się potencjalnymi nieprawidłowościami.

${ }_{23}$ G. Reale, Historia filozofii starożytnej, t. 1, przeł. E.I. Zieliński, RW KUL, Lublin 1994, s. 331-335. 
Pierwsza możliwość jest jednak nieakceptowalna. Stwierdzenie braku wpływu na własne postawy i odczucia związane $\mathrm{z}$ winą zakłada całkowity brak autonomii jednostki. To z kolei stoi w sprzeczności z podjętą przez radykalne stanowisko obroną autonomii. Dlatego, że zakłada obronę czegoś, co de facto nie istniałoby przy powyższym założeniu.

Druga możliwość, jest trudniejsza do rozstrzygnięcia. Trudno bowiem ważyć korzyści i straty poniesione przez z jednej strony społeczeństwo funkcjonujące bez poczucia winy (składające się z jednostek pozbawionych poczucia winy), a z drugiej strony przez jednostkę posiadającą takowe poczucie w wyniku naruszenia jej autonomii. Sądzę, że dylemat ten rozwiązałaby inna nieco propozycja zwolenników ujęcia radykalnego. Gdyby udałoby się wykazać, że poczucie winy nie jest konieczne do tego, aby ludzie byli moralni i odpowiedzialni za uczynione zło, wydaje się że społeczna rola poczucia winy mogłaby zostać zastąpiona. W artykule Nebletta taka propozycja nie pada. Samo z kolei poczucie winy, oprócz dosyć nieprzyjemnego emocjonalnego aspektu, posiada w sobie głębszą warstwę. Jest nią świadomość zła, z którym jest się jakoś związanym. Oba elementy wydają się ze sobą zestrojone na tyle silnie, że jeśli ktoś ma świadomość, że wyrządził zło, a nie posiada związanych z tym przykrych emocji, uznawany jest za kogoś w najlepszym razie niewrażliwego, a w najgorszym niemoralnego. Coś, co mogliby zaproponować radykałowie, musiałoby więc nadal wiązać podmiot ze złem, ale bez owych przykrych emocji, przy pomocy których społeczeństwo może wpływać na jednostkę. Tutaj pojawia się pytanie, czy zwolennikom radykalnego ujęcia zależy na wyrugowaniu zarówno owego poczucia powiązania ze złem, jak i nieprzyjemnych emocji, czy tylko tych ostatnich. Trudno zaakceptować pierwszą możliwość, dlatego że chroniąc autonomię, jednocześnie proponowanoby kompletną amoralność. Co wydaje się o tyle wewnętrznie sprzeczne, że obrona autonomii jednostki wobec zakusów społeczeństwa musi być jakoś uzasadniona jako lepsza, moralnie lepsza. Zatem nie można $\mathrm{w}$ imię moralności proponować amoralności, chcąc jednocześnie zachować wewnętrzną spójność własnych poglądów. Pozostaje więc, że tym, co chcą wyrugować radykałowie, jest owa nieprzyjemna emocja. A dokładniej jej potencjalna siła obezwładniania, czynienia poddanym wpływom społecznym. Tutaj jednak, należy zauważyć, że o owym zniewalającym wpływie decyduje nie tylko społeczeństwo, ale także dana osoba.

Zatem są dwa elementy, które mogą wpływać na rolę poczucia winy: społeczeństwo i dana osoba. Radykałowie, chcąc na wszelki wypadek chronić osobę, proponują całkowicie odrzucić poczucie winy. To jednak okazać się może niekorzystne dla społeczeństwa, o ile nie przedstawi się innego wiązania między czynem a osobą w miejsce poczucia winy. Póki to nie nastąpi, korzystniej dla społeczeństwa będzie zarówno unikać nadużyć we wzbudzaniu poczucia winy, jak i wychowywać swoich 
członków na osoby autentycznie przeżywające poczucie winy, dzięki czemu mogłyby one zachować autonomię również wobec własnej winy.

Przyglądając się radykalnej krytyce poczucia winy referowanej przez Nebletta, zauważyć też można nazbyt daleko idące uogólnienie pojęcia egoizmu. W cytowanym wyżej fragmencie pada stwierdzenie, że czyny osoby etycznie dobrej „nie mają źródła w czysto egoistycznym pragnieniu stłumienia przykrych uczuć, a zwłaszcza przykrego poczucia winy" ${ }^{\prime 2}$, które to prowadziłoby do jakieś formy przeproszenia za wyrządzone zło. Sformułowanie to jest wieloznaczne. Nie wiadomo bowiem, czy chodzi o to, że osoba etycznie dobra nie powinna nigdy tłumić własnych wyrzutów sumienia z pobudek innych niż altruistyczne; czy też tłumienie przykrych uczuć (w tym uczucia winy) zawsze jest egoistyczne; czy też tłumienie to bywa egoistyczne jedynie czasami. Dla wyrazistości mojej krytyki przyjmę mniej radykalne sformułowanie i będę intepretować powyższą wypowiedź jako mówiąca, że tłumienie przykrych uczuć (w tym poczucia winy) czasami bywa egoistyczne. Przedstawię natomiast argumentację, która wykazuje, że tłumienie poczucia winy nigdy nie jest egoistyczne. Może jednak być egocentryczne lub/i nieszczere. Przez egocentryzm rozumiem tutaj niechęć lub nieumiejętność współczucia innej osobie, skutkujące patrzeniem na daną sytuację tylko z własnego, podmiotowego punktu widzenia ${ }^{25}$. Z kolei egoizm w cytowanej wypowiedzi rozumiany jest jako jakiekolwiek działanie przynoszące korzyść działającemu lub nawet jakiekolwiek działanie interesowane. Odwołując się do artykułu K. Twardowskiego „Czy człowiek zawsze postępuje egoistycznie?", przyjmuję jednak, że „,egoistą nazywamy człowieka, który przysparza sobie przyjemności bez względu na to, czy własną przyjemność okupuje cudzą przykrością, czy nie; kto szuka zadowolenia własnego, a nie zważa, że warunkiem osiągnięcia własnego zadowolenia jest niezadowolenie cudze, ten jest egoistą"26. Zatem samo poszukiwanie przyjemności lub unikanie nieprzyjemności nie jest jeszcze działaniem egoistycznym. Byłoby takim, gdyby przeprosiny, znoszące przykre poczucie winy, jednocześnie szkodziły tej osobie, którą się przeprasza i przepraszający miałby tego świadomość. Trudno jednak wyobrazić sobie, że przepraszanie kogoś, tego kogoś krzywdzi. Co więcej, samo poczucie ulgi, czy też spokoju towarzyszące przepro-

24 W. Neblett, Etyka winy, w: Filozofia moralności..., op. cit., s. 76.

25 Podążam tutaj za psychologicznym określeniem egocentryzmu: „,egocentryzm [łac.], psychol. postawa, sposób myślenia, dla których charakterystyczne jest ujmowanie rzeczywistości z punktu widzenia własnej osoby i własnych przeżyć oraz absolutyzowanie własnego stanowiska wobec otoczenia", za: http://encyklopedia.pwn.pl/ haslo/3896721/egocentryzm.html, 07.10.2011.

26 K. Twardowski, Czy człowiek postępuje zawsze egoistycznie?, w: O wartościach, normach i problemach moralnych: wybór tekstów z etyki polskiej dla nauczycieli i uczniów szkót średnich, WN PWN, Warszawa 1994, s. 352-353. 
szeniu i uzyskaniu przebaczenia, nie oznacza jeszcze, że jedynym celem działania jest tutaj chęć uzyskania takowego poczucia ulgi czy spokoju. Tego typu uproszczenie spotkało się również z krytyką w cytowanym artykule K. Twardowskiego, który uważa, że podobne uczucia chcąc nie chcąc towarzyszą ludzkim czynom, ale nie koniecznie są ich celem ${ }^{27}$. Trudno się więc zgodzić z uproszczeniami i uogólnieniami, w które wpada zwolennik wersji radykalnej, a które mają wspierać argumentację za częściowym odrzuceniem poczucia winy jako wymaganej reakcji moralnej. Przedstawiony argument nie przeczy jednak temu, że przeprosiny mogą mieć na względzie tylko i wyłącznie chęć pozbycia się nieprzyjemnego poczucia winy, a nawet, że mogą w ten sposób być nieszczere. Może się tak stać, gdy przepraszający czyni to tylko i wyłącznie z intencją pozbycia się własnego nieprzyjemnego uczucia i społecznego napiętnowania, nawet za cenę faktycznego nieuznania własnej winy. Taka postawa niewątpliwie jest szkodliwa, przede wszystkim dla tego, kto w ten sposób oszukuje innych i czasem samego siebie. W akcie przeproszenia trudno jednak od razu doszukiwać się nieszczerych czy egocentrycznych intencji. Argument Nebletta z kolei można więc intepretować tak, że odrzucając poczucie winy u osób moralnie dobrych stara się on zabezpieczyć niejako teoretycznie, na wszelki wypadek, owe podmioty przed nieszczerym poczuciem winy, które niejako nadwyrężyłoby ich moralną dobroć. Problem jednak w tym, że chronienie przed jednym niebezpieczeństwem, owej nieszczerej i egocentrycznej motywacji, odbyć się ma za sprawą wyrugowania poczucia winy, które z kolei nie zawsze jest egocentryczne i nieszczere. Gdyby bowiem takie miało być, to Neblett musiałby je odrzucić również u bardzo złego człowieka, gdyż pogarszałoby to jego stan moralny, na co, jak sam stwierdza, a co zostało ukazane powyżej, nie można się zgodzić. Skoro więc, poczucie winy okazuje się jednak czasami konieczne dla bycia moralnym, nie zawsze jest egocentryczne lub nieszczere; albo też mimo że jest egocentryczne i nieszczere, to okazuje się jednak moralnie potrzebne. Pytanie: dlaczego? Jak sądzę, poczucie winy, nawet jako wytwór społeczeństwa (dla siły argumentu idę tutaj na ustępstwo względem Nebletta), nawet narzucane jego członkom, okazać się może konieczne do powstania współczucia wobec osoby skrzywdzonej i częściowego chociaż przekroczenia egocentryzmu. Bowiem nawet gdyby założyć, że zwłaszcza u małych dzieci, poczucie winy i akt przeproszenia nie są autonomiczne, szczere i przekraczające egocentryzm, nie oznacza to, że nie mogą takimi się stać wraz z rozwojem osobowości i autonomii moralnej, a genezą tej dojrzałej postawy może być oddziaływanie społeczeństwa. Społeczeństwo to przecież, jak referuje Neblett, krytykuje również nieszczere poczucie winy. Sama z kolei autonomia okazać się może również wówczas, gdy

27 Ibidem, s. 354-355. 
posiadając poczucie winy, nie chce się nieszczerze lub bez współczucia (przeciwieństwo egocentryzmu) przeprosić osoby pokrzywdzonej i ma się odwagę znosić nieprzyjemne uczucia napiętnowania i poczucia winy. Samo więc poczucie winy nie jest $\mathrm{w}$ konieczny sposób przeciwieństwem autonomii i dojrzałości moralnej. Bez niego zaś, ponieważ Neblett nie proponuje jakieś innej formy powiązania podmiotu $\mathrm{z}$ wyrządzonym złem, trudno mówić o poczuciu odpowiedzialności i konieczności przeproszenia za wyrządzone zło. Ostatnie uwagi, o ile skutecznie przeciwstawiają się wersji złagodzonej Nebletta, o tyle tym bardziej odnoszą się do stanowiska radykalnego.

\section{Podsumowanie}

W artykule przedstawiłem własną interpretację sporu Nebletta i Kavki, starając się ukazać źródło pozornego nieporozumienia jakie zauważyć można w uwagach Kavki. Mimo że obaj autorzy inaczej rozumieją możliwość posiadania poczucia winy bez odpowiadającego jemu czynu, argumenty Kavki wydają się podważać teoretyczną konstrukcję Nebletta, gdyż ukazują konieczność poczucia winy dla bycia moralnym.

W części prezentującej własną analizę stanowiska Nebletta, starałem się pokazać, że nawet złagodzona wersja radykalna jest trudna do zaakceptowania, gdyż nie proponuje niczego w zamian poczucia winy, czym może uniemożliwić autonomiczne poczucie odpowiedzialności za wyrządzone zło i pragnienie jego naprawienia.

Wykazałem też, że argumentacja radykalna posługuje się zbytnim uogólnieniem i uproszczeniem $\mathrm{w}$ pojmowaniu egoizmu jako potencjalnego motoru skłaniającego do naprawienia zła.

Niewątpliwie docenić trzeba wagę problemów nieszczerego i wymuszonego poczucia winy, a także przesadnego używania tej kategorii $\mathrm{w}$ relacjach międzyludzkich, na jakie zwraca uwagę stanowisko radykalne i Nebletta złagodzenie tegoż stanowiska. Starałem się jednak wykazać, że propozycja odrzucenia poczucia winy, nawet u osób moralnie dobrych, jest słabo uzasadniona. Potencjalna nieszczerość, czy egocentryzm nie są bowiem koniecznie związane z poczuciem winy. Co więcej, autonomia moralna nie jest czymś niezależnym od danego podmiotu i pochodną tylko społecznych nacisków, ale zależy od danego podmiotu. Zależność tę widać też $\mathrm{w}$ odmowie przeproszenia, o ile podmiot stwierdzi, że uczyniłby to nieszczerze lub bez współczucia. Sama z kolei społeczna geneza poczucia winy i naciski na to, aby je odczuwać, owej autonomii nie niweczą w sposób konieczny. Natomiast odrzucenie, na wszelki wypadek, poczucia winy jako nośnika owego społecznego przymusu, może osłabić moralność danej osoby, gdyż pozbawi ją możliwości jego odczuwania, a co za tym idzie możliwości współczucia i naprawie- 
nia wyrządzonego zła, jak również pytania o własną autonomię, którą społeczeństwo z jednej strony potrafi wspierać (żądaniem szczerości), ale i podważać przesadnym podkreślaniem poczucia winy.

Sugerowane rozwiązanie tego problemu polegałoby albo na znalezieniu i propagowaniu innego, niż czasem zniewalające poczucie winy, połączenia między podmiotem a uczynionym przez niego złem (co wydaje się bardzo trudne), albo na próbie wyrugowania, nie samego poczucia winy, ale nadużyć w „posługiwaniu” się nim. Propozycja Nebletta, o tyle w tym kontekście jest też nie pełna, że podmioty moralnie jeszcze niezbyt dobre pozostawia pod wpływem zarówno poprawnego jak i szkodliwego oddziaływania społeczeństwa.

\section{Streszczenie}

\section{Kilka uwag na marginesie sporu między Gregorym S. Kavką a Williamem Neblettem o poczucie winy}

\section{Słowa kluczowe}

wina; poczucie winy; Neblett; Kavka; egoizm; autonomia; szczerość

Artykuł przedstawia dyskusję na temat roli poczucia winy w moralności między Williamem Neblettem a Gregorym Kavką. Neblett krytykuje tradycyjne pojęcie roli poczucia winy i próbuje uzasadnić pogląd, że poczucie to może być oderwane od realnej winy. Z kolei Kavka broni, z pewnymi modyfikacjami, stanowiska tradycyjnego. Oprócz prezentacji argumentów obu stron, artykuł zawiera próbę wyjaśnienia drobnego nieporozumienia, które zaistniało między Neblettem a Kavką. Przedstawia dodatkowe argumenty przeciw całkowitemu odrzuceniu poczucia winy. Artykuł broni też poczucie winy przed przypisywaniem jemu jedynie egoistycznej motywacji.

\section{Summary}

\section{A few remarks about debate of Gregory S. Karka and William Neblett concerning sense of guilt}

\section{Keywords}

fault; sense of guilt; Neblett; Kavka; selfishness; autonomy; honesty 
This paper presents a discussion on the role of guilt in morality, between William Neblett and Gregory Kavka. Neblett criticizes the traditional concept of the role of guilt and trying to justify the view that sense of guilt can be detached from the real guilt. On the other hand Kavka defends, with some modifications, the traditional position. In addition to the presentation of the arguments on both sides, the article includes an attempt to explain the small misunderstanding which existed between Neblett and Kavka. The paper provides additional arguments against the total rejection of guilt. And also advocates sense of guilt from attribution to it only selfish motivation.

\section{Bibliografia}

Encyklopedia PWN, http://encyklopedia.pwn.pl/haslo/3896721/egocentryzm.html, 07.10.2011, hasło: egocentryzm.

Giebułtowski J., Piłat R., Przyznanie się. Teoretyczne trudności związane z przypisywaniem sobie działań, w: Filozofia chrześcijańska, Stachewicz K. (red.), t. 9, Poznań 2012, s. 51-70.

Hołówka J. (red.), Filozofia moralności. Wina, kara, przebaczenie, tłum. Dariusz Gałecki, A. Lipszyc, P. Łuków, M. Rychter, Ł. Sommer, S. Stecko, Fundacja Aletheia, Warszawa 2000.

Kavka G. S., Zły czyn i wina, w: Filozofia moralności. Wina, kara, przebaczenie, Hołówka J. (red.), przeł. D. Gałecki, A. Lipszyc, P. Łuków, M. Rychter, Ł. Sommer, S. Stecko, Fundacja Aletheia, Warszawa 2000, s. 81-82.

Neblett W., Etyka winy, w: Filozofia moralności. Wina, kara, przebaczenie, Hołówka J. (red.), przeł. D. Gałecki, A. Lipszyc, P. Łuków, M. Rychter, Ł. Sommer, S. Stecko, Fundacja Aletheia, Warszawa 2000, s. 66-80.

Reale G., Historia filozofii starożytnej, t. 1, przeł. E.I. Zieliński, RW KUL, Lublin 1994, s. 331-335.

Stachewicz K. (red.), Filozofia chrześcijańska, t. 9, Poznań 2012, s. 7-89.

Strzyżyński P., Problem trafu moralnego i winy wedtug Thomasa Nagela i Norvina Richardsa, w: Filozofia chrześcijańska, Stachewicz K. (red.), t. 9, Poznań 2012, s. 71-89.

Twardowski K., Czy człowiek postępuje zawsze egoistycznie?, w: O wartościach, normach i problemach moralnych: wybór tekstów z etyki polskiej dla nauczycieli i uczniów szkół średnich, WN PWN, Warszawa 1994, s. 352-355.

Wieczorek K., Skąd przychodzi wina? Aksjologiczne i dialogiczne źródła zawinienia, w: Filozofia chrześcijańska, Stachewicz K. (red.), tom. 9, Poznań 2012, s. 23-38.

Wierzbicki A., Wina i sumienie. Komentarz etyczny do epilogu "Zbrodni i Kary" Fiodora Dostojewskiego, w: Filozofia chrześcijańska, Stachewicz K. (red.), t. 9, Poznań 2012, s. 39-50.

Wiśniewski R., Wina jako węzeł moralności, w: Filozofia chrześcijańska, Stachewicz K. (red.), t. 9, Poznań 2012, s. 7-21. 